\title{
Perception of CSR by SME Managers: A Contextualist Analysis in the Forest Industry Sector in Cameroon ${ }^{1}$
}

\author{
Dr Isaac Bernard NDOUMBE BEROCK* \\ Lecturer-researcher, Advanced School of Economics and Commerce - ESSEC, University of Douala, (UDo) \\ and BETA-University of Strasbourg
}

\begin{abstract}
*Corresponding Author: Dr Isaac Bernard NDOUMBE BEROCK, Lecturer researcher, Advanced School of Economics and Commerce (ESSEC), University of Douala, (UDo) Cameroon and BETA-FSEG, University of Strasbourg, France.
\end{abstract}

\begin{abstract}
Corporate Social Responsibility (CSR) is built over time into an imperative for any organization (large, small and very small), including in developing countries. The central role that the leader plays in the decision-making process in small and medium-sized enterprises (SMEs) and very small enterprises (TPE) is a fruitful field of research to study his/her perception of the concept of CSR. The prevailing normative and empirical literature on the perception of CSR by the leaders of these companies over the last three decades led them to adopt, in their turn, mimicry of such practices, cogitating on the beneficial effects that are very often associated with them. However, notwithstanding the abundant literature devoted to CSR in these organizations, the empirical research dedicated to the perception of the "top manager" of these structures, specifically in the African context remains very limited. Based on the assumption that forest certification is likely to be a distinctive variable in the perception of CSR, a qualitative study was conducted among the strategic actors of four Cameroonian SMEs in the forest industry, two of which Forest Stewardship Council (FSC) certified and two uncertified reveals (1) a small distinction between the two groups regarding not only their knowledge and appropriation of the concept of CSR, (2) the identification of motivations but above all (3) some challenges to the commitment of the organization.
\end{abstract}

Keywords: Manager Perception, Certification, Forestry Sector, Strategic Actors, Contingent CSR Practices, Cameroun.

\section{INTRODUCTION}

In an uncertain environment, littered with many challenges (climate change, violent hurricanes, loss of biodiversity, etc.), corporate social responsibility (CSR) is positioning itself as a growing field of interest for both academics and practitioners,, especially in theoretical and practical terms. At the same time, the attention of the public and the actions of governments, the international community and civil society (NGOs) to promote the protection of the environment, CSR is no longer focused exclusively on large companies (Berger Douce, 2009), it is exponentially migrating to the majority of companies qualified as SMEs and VSEs, including in developing countries (Paradas, 2006, Ngaha Bah et al., (2016), Simen and Ndao, 2013, Ben Hassine and Ghozzi-Nékhili, 2013). In this respect, an impressive literature dedicated to CSR reveals the need to deepen knowledge first and foremost on the corporate culture and the relational framework that can condition the economic and social functioning of SMEs (Spence et al. , 2007). A multitude of both national and international standards such as ISO 9001 dedicated to quality, essential for customer sensitivity, ISO 14001 for the respect of the environment and OHSAS 18001 favorable to the health and safety of employees, etc. and certifications, especially the Forest Stewardship Council (FSC) were created essentially in a bid to provide companies with standard and proven tools, necessary not only to internalize the negative externalities of their activities (Ndoumbe Berock, 2017), but also to take into account the concerns of all stakeholders.

Despite the extensive literature on CSR in organizations, empirical research on CSR has focused more on big business. This research has done very little to highlight the practices of contingent SMEs in

\footnotetext{
${ }^{1}$ I would like to show my sincere appreciations to Dr Henry BIAHE, Linguistics and Translation Studies, University of Saskatchewan in Canada, for helping me to give the best for this article
} 
this area (Berger-Douce, 2009, Gendre-Aegerter, 2008, Quairel and Auberger, 2005, and Lapointe and Gendron, 2004) thus obscuring their inherent characteristics.. In the opinion of Torres (1997), this failure has as a corollary a significant challenge to the specificities of this type of organization. For some authors, like Ben Hassine and Ghozzi-Nékhili (2013) and Gendre-Aegerter (2008), one of the major specificities of SMEs is the main place of cognitive patterns of leaders in the design of the strategy. This paper focuses on the perception of CSR leaders in Cameroon's forestry sector. To this end, we have formulated the question that constitutes the thread of our research as follows: How do the managers of certified and non-certified SMEs in the Cameroonian forest sector perceive CSR? As part of this research, we make a point of honor not only on the realities, but also on the CSR issues in the context of Cameroonian SMEs in the forest industry sector as perceived by leaders very closely associated with that of their company (Paradas, 2011, Berger-Douce, 2009). To achieve this, an exploratory study was conducted with the leaders of four Cameroonian SMEs in the forest industry engaged explicitly or not in a CSR approach via Forest Stewardship Council (FSC) certification. This will enable us to be part of a comparative approach to the different perceptions of CSR of its actors in order to identify the explanatory factors.

This research is structured around four major points. The first point will shed theoretical light on the concept of CSR, its normative foundations as well as its specificities in the SME context. The second point will focus exclusively on managerial cognition. The third point is reserved for methodological choices. Finally, the fourth point deals with the discussions of the results and the managerial implications.

\section{NORMATIVE BASES AND SPECIFICITIES OF CSR IN AN SME CONTEXT}

Corporate Social Responsibility (CSR) has been receiving increasing attention since the beginning of this millennium and enjoys strong media coverage, including in developing countries (Ndoumbe Berock, 2017). This concept is very often mobilized as the managerial translation that leads to the operationalization of sustainable development (Pia Imbs and LovanirinaRamboarison-Lalao, 2013, Boubaker-Gherib, 2009). For Ben Hassine and Ghozzi-Nekhili (2013), CSR is the contribution of companies to sustainable development (SD) resulting in a triple performance, particularly economic, environmental and social. In the same vein, Capron and Quairel-Lanoizelée (2007) emphasize that SD emanates from public policies at the macro-societal level, unlike CSR, which refers to microeconomic business practices. For these authors, it is very difficult to master the articulations between these two related concepts.

Several definitions and interpretations have been attributed to the concept of CSR by an abundance of scientific literature (Carroll, 1979, 1991, Clarkson, 1995, Wood, 1991, Capron and QuairelLanoizelée (2007) with which a multitude of modelizations of the same concept need to be associated. (Carroll, 1979, Quazi and O'Brien, 2000, Durif, 2006, Meehan et al., 2006), notwithstanding this dominant literature, this concept is still awaiting consensus (Christine Noël, 2004, Déjean and Gond , 2004) It is probably in this logic that Matten and Moon (2005) argue that CSR is a generic term that is both ambiguous and complex with a disputed meaning. In general, this concept is perceived as a managerial translation of sustainable development issues (Ndoumbe Berock, 2017), which is why the ISO 26000 standard defines CSR as:

"the responsibility of an organization vis-à-vis the impacts of its decisions and activities on society and the environment, reflected in a transparent and ethical behavior that contributes to sustainable development, health and well-being of society; takes into account stakeholder expectations, complies with applicable laws and is in line with international standards of behavior; and that is integrated throughout the organization and implemented in its relationships".

\subsection{Normative Underpinnings of CSR}

As far as the normative aspect is concerned, there has been an undeniable increase in the different types of regulation in recent decades. Not only are there many new regulatory instruments, such as international standards, codes of conduct (Global Compact, OECD Guidelines, etc.), but also many new active regulators, including labels or standards (SA 8000, ISO 14001, ISO 26000, etc.), forestry certifications (FSC, PEFC, PAFC, etc.) associated with purely state actions or measures (Braithwaite and Parker, 2004). These references, which stem from the deliberate policies of countries and movements of social and environmental activists (non-state actors), are specifically aimed at 
stimulating businesses to engage in sustainable development approaches through the implementation of CSR actions (environmental protection, respect for human rights, fight against corruption, respect for fundamental rights at work, etc.) on a purely voluntary basis (Ben Hassine and Ghozzi-Nekhili, 2013).

Other regulatory instruments are becoming increasingly popular and prominent around the world, including in developing countries, and are used to regulate the use and / or protection of biodiversity, climate, and so on.

The regulation of sustainable forest management has diversified over time in the same way as other forms of environmental regulation. Many changes have been noted in both form and content. For example, in many countries, including wood production, the new forest management standard included both sustainable forest management and biodiversity protection, yet in the past these objectives were separated into different regulations and were specific to different geographical areas (McGinley and Cubbage, 2011). In the opinion of Pappila, (2011), it is "the noticeable change in the content of state and non-state forest regulations over the last two decades" which is thus added to the many regulatory instruments specific to the sustainable management of forests that emerged since 1990. As a result, forest certification is, for example, a new type of instrument designed to combine the triptych 'economic, social and ecological' sustainability, thus representing commitment to a CSR approach.

It is therefore obvious to note an impressive number of reference standards devoted to evaluating CSR practices implemented by companies, particularly those in the forestry sector. Examples of sustainable management or environmental protection tools include the Environmental Management and Audit Scheme (EMAS), which is an initiative of the European Union. This instrument has the particularity of clarifying the different stages or processes of voluntary participation of companies in environmental management audit systems. The Social Accountability Standard 8000 (SA 8000) is a standard that was initiated by the Council on Economic Priorities and piloted by Social Accountability International (SAI) regarding working conditions, the proscription of child labor, etc. The International Organization for Standardization (ISO) has implemented a series of initiatives, including the series of 14000 standards specific to environmental management. The ISO 14001 standard is the most prominent series of standards whose purpose is to measure the impact of any business activity on the environment. We also have the ISO 9000 series specific to quality management. The latest and most recent series of standards developed by the International Organization for Standardization is the ISO 26000 standard. Created in 2010 and revised in 2016, this standard has been established over the years as an indisputable reference for companies in driving responsible (Trébucq, 2010).

\subsection{State of Affairs Regarding the Literature on CSR in an SME Context}

Although considered by some authors like Lapointe and Gendron, (2004) as a relatively recent concept, especially in the SME context, CSR is attracting more and more attention from researchers (Paradas, 2006). Berger-Douce, 2007, Gendre-Aegerter, 2008), including in Africa (Ngaha Bah et al., (2016), Ben Hassine and Ghozzi-Nekhili, 2013, Simen and Ndao, 2013, OndouaBiwolé et al., 2008). Conscious of the fact that the theories mobilized within the framework of the large enterprise can only partially or not be applied in the SME context (Ben Hassine and Ghozzi-Nékhili, 2013, Jenkins, 2009), many works have set out to build a theoretical framework specific to CSR in these entities (Quairel and Auberger 2005, Paradas 2006, Berger-Douce 2007, 2009, OndouaBiwolé et al., 2008, Gendre-Aegerter 2008, Jenkins 2009, Ben Boubaker-Gherib 2009). Nielsen and Thomson, 2009, Labelle and St-Pierre, 2010, Labelle and Aka, 2010, Abdirahman and Sauvée, 2011, Ben Hassine and Ghozzi-Nékhili, 2013). For Torrès (1997), the specific nature of these small economic entities justifies the issues and challenges they face, particularly in terms of integrating the principles of responsible management that correspond to particular motivations (Ben Boubaker-Gherib et al. , 2009). According to Spence et al., (2007), there is little distinction in the SME between the management and ownership roles. For these authors, positions within this type of organization are multitasking. These entities are primarily oriented towards solving or managing daily problems. Spence and Lozano, (2000) point out that in this type of organization, informal relations and communication are very prominent and interpersonal relationships are more important. For Abdirahman and Sauvée (2011), there is a very important degree of interrelationship between these entities and their environment, particularly with the communities in which they operate; acting very 
often as sponsors, benefactors or local activists. In addition, the majority of the methodological approaches implemented in these companies have been designed to be applicable to large entities, in order to integrate into their management style a "business ethics" that takes into account the concerns of their stakeholders. This is undoubtedly what justifies the fact that Ben Hassine and Ghozzi-Nékhili (2013) argue that these methodologies related to CSR are likely to take into account criteria inappropriate to the realities of this type of organization.

Thus, the lack of implementation of these so-called globalized methods requires us to mobilize these methodologies specific to large companies as references or parameters that can be used to assess the management of CSR for contingent SMEs. By postulating that CSR is essentially alluding to the consideration of ethical concerns, it is very easy to analyze responsible management in order to adapt it to the SME. In this logic, we better understand the motivations of Quairel and Auberger (2005) to build a CSR-oriented strategic reading grid that is specific to SMEs.

These authors favor the stakeholders theory as an adequate theoretical framework for modeling CSR in all types of organizations regardless of size.Contrary to what happens in big business, the relationship that binds the leader of the SME and these stakeholders is a relationship of dependence on resources to an agency relationship (Ben Hassine and Ghozzi-Nekhili, 2013). In this respect, Ben Boubaker-Gherib et al. (2009) have developed a theoretical framework specific to the engagement of SMEs based in the Global South in a sustainable development approach.

These authors reveal that the neo-institutionalist theory that the company is embedded in a social milieu (DiMaggio and Powell, 1983) associated with the entrepreneurial theory dedicated to the specific values of the leaders are the best adapted to scrutinize this commitment. In their work, Spence et al., (2007) argue that both economic and organizational approaches prompt those who call them to claim that corporate ownership of societal values or simply CSR is rooted in the principles of corporate social responsibility organizational and environmental criteria (Spence et al., 2007, Spence, 1999). These authors point out that while this is true for large companies, the fact remains that, although important, organizational criteria are not a catalyst for an SME approach to CSR because of the dominant role of the leader. It is therefore obvious to understand the reasons why similar SMEs in terms of both organizational and environmental criteria, driven by people with different characteristics, cannot all be part of a CSR-oriented strategy (Spence (1999). The strong centralization recognized in SMEs gives the manager and its goals a place of choice, which is probably why Paradas (2006) reveals that in its small structure, the manager is the only master on board. In the same vein, Bayad and Garand, (1998) make it clear that everything in the future of the company will depend on the vision of its leader. In this context, the leader will be comparable to a pivot, or better still to the instigator of CSR and will appear as the bearer of an ethics in relation to the concept of stakeholders (Paradas, 2006). Ethics is posited here by this author as a report to others and the leader can only for that purpose represent the interest of others (Ben Hassine and Ghozzi-Nékhili, 2013). The important stakeholders who put pressure on the company most often have contradictory desires and the manager is very often tempted to worry about satisfying his selfish interests. It is in this logic that Paradas (2006) equates the leader with a stakeholder in the same way as the others.

Notwithstanding this status, it has the particularity that its opinion on the operation or the strategic decisions of its company is preponderant of all the others. In this same vein, Berger-Douce (2007) develops a matrix of societal engagement strategies for leaders or entrepreneurs who cross environmental commitment and social commitment to integrate the diversity of entrepreneurial approaches with respect to the strategy of their business. To this end, four different strategies have been identified, namely the proactive strategy, the ritual strategy, the mobilizing strategy, and the reactive strategy. It should be noted that according to its author, this "matrix is conceived as a tool likely to change the thinking patterns of entrepreneurs" (Berger-Douce, 2007, 67). This reinforces or consolidates the point of view of Ben Boubaker-Gherib et al. (2009) for whom CSR is a construction that is both social and cognitive, requiring a conceptual model that integrates the perceptions of managers as a priority. Ben Hassine and Ghozzi-Nékhili, (2013) reveal that the model of these authors is focused on a typology of perceptions integrating the "must do" and the "want to do".

In reference to this approach, the commitment of SMEs to CSR is essentially based on the personal values of the manager. According to Jenkins (2009), this personification of the organization's strategy, which essentially relies on the model described as "business opportunities" in an SME context, gives 
the manager the opportunity to significantly influence both the values and the organizational culture. The central role of eating in the design of the CSR-oriented strategy has been validated by some works, notably those of Abdirahman and Sauvée (2011) in the field of SMEs in the agri-food context. For Ben Hassine and Ghozzi-Nékhili, (2013) this role is essential, especially during the awareness period during which the company strives to increase its awareness of the issues and importance of CSR. Some authors, like Fassin et al., (2011) equate this with a moral duty or even an obligation to integrate the concerns of these stakeholders into management modes. This review of the literature shows that research on CSR in the SME context is in full swing and that the epistemological and theoretical foundations in the opinion of Labelle and Aka, (2010) relating to this issue are under permanent construction.

However, it should be noted that this is a very fruitful field of research that increasingly captivates both many researchers and practitioners, particularly SME managers, including those in developing countries. In view of the above, it is therefore interesting and relevant to dwell on the perceptions of SME leaders about CSR. This will enable us to better understand and analyze CSR practices in an SME context.

\section{THEORETICAL FrAMEWORK AND METHODOLOGY}

\subsection{Theoretical Framework Mobilized: Managerial Cognition}

Like the works of many authors, notably those of Gendre-Aegerter (2008) and Ben Hassine and Ghozzi-Nékhili, (2013), we also used managerial cognition to constitute the theoretical framework of this research. And in order to outline a definition of managerial cognition, a preliminary clarification of the notion of cognition seems essential. Codol (1989), adopted by Gendre-Aegerter (2008), considers that cognition is "the set of activities by which all the information that the individual receives is processed by a psychic apparatus: how he receives them, how he selects them" how he transforms and organizes them, and how he constructs representations of reality and develops knowledge. " In the same vein, Cossette $(2008$, p.3) argues that "cognition is linked to thought or knowledge. Most often, it refers to a particular function with associated activities or processes related to human intelligence. In general, the study of cognition concerns the processing of information and the knowledge that permits or results from it." For this author, studies on organization necessarily take into account the cognitive dimension (Cossette, 2008). In the same vein, Schneider and Angelmar (1993) reveal that, usually, two levels of analysis are recognized in the cognitive approach to organizations, particularly the individual or managerial level and the organizational or collective level.

The individual or managerial level admits that managerial cognition is learned at the individual level. This approach is based on the idea that the review of the leader's mental process is more appropriate to understand the evolution of the formulation of his strategy. In this logic, individual cognition is primarily concerned with the decision-making process. The organizational or collective level equates the organization with a set of social interactions Gendre-Aegerter (2008). The appropriation of work on cognition by the organization has led to the emergence of other types of organizational behavior such as change, learning and performance. It is with a view to corroborating these claims that Walsh (1995) in his works on managerial and organizational cognition announces the existence of a profusion of fields of investigation. This author identifies in his works other research related to not only the content of the structure of knowledge but also the level of analysis and their empirical or theoretical character. This research also takes into account that the fact that his work is based on the development, representation or use of knowledge (Gendre-Aegerter, 2008).

Although interesting to prioritize the abundant literature in relation to their relevance; nevertheless, it is important to note the inadequacies of these models, which do not provide sufficient information on how to exploit the concept of cognition through this research (Ben Hassine and Ghozzi-Nékhili, 2013). It is in this context that Meindl, Stubbart and Porac (1994) observe almost an absence not only of nomenclature of cognitive terms but also unanimity as to what must be qualified as cognitive and what is not. In the same vein, Cossette, (2008) argues that the extension of the vocabulary assimilated by some authors on cognition, notably belief, representation, interpretation, etc., seems to exist contrary to the concept of cognition or its dismemberments often obscured (Meindl et al., 1994).

Generally speaking, it is clear that the people who constitute an organization are not passive actors who receive or are subject to external pressures, their actions are related to their values and beliefs. It 
is probably for this reason that Ben BenHassine and Ghozzi-Nékhili, (2013) emphasize that the behavior of the organization reflects that of the people who compose it. In such a context, an organization is thus perceived as the result of the cognition of its actors, in particular of its manager with regard to the specific case of the SME. The work of Mintzberg (1973) and to a certain extent Gupta (1984) is a reference in business strategy research that is particularly focused on managerial cognition. In their work, these authors admit that the strategy is an aggregate of essentially punctual decisions that is closely related to the mental functioning of the manager of the company.

In the same vein, Gendre-Aegerter, (2008) reveals that the cognitive approach of organizations argues that the thought of the leader is the driving force to promote not only the understanding but also and above all the explanation of his strategic decisions.

Lauriol, (1998), for its part, announces the emergence in recent decades of a new field of fruitful research that integrates new cognitive dimensions. For this author, the rationality of the decisionmaking process, especially of the leaders, is essentially questioned in this new disciplinary field (Lauriol, 1998). He also pointed out that this line of research based on managerial cognition culminated in the 1990s with abundant work especially on the steps of decision-making and the formation of strategies (Gendre-Aegerter, 2008, Lauriol, 1998). In the same vein, Gendre-Aegerter, (2008) and Cossette, (2008) argue that research based specifically on the meaning that leaders give to the concerns of their immediate environment is the raison d'être of studies in managerial cognition. Following this logic, the foundation of managerial cognition is in this case linked to the importance it gives to elements that are essentially cognitive in nature, as in the case of better perception, of interpretation in relation to the constitution of managerial thinking (Lauriol, 1998).

In the perspective of a cognitive approach and far from being assimilated to an organization subject to a set of scientific laws, Cossette (2003) conceives the organization as being a total or at least partial creation of the individuals who compose it and act essentially on her (Ben Hassine and GhozziNekhili, 2013). Likewise, Ehlinger (1997) reveals that the perception of the image of the company has deeply changed from an essentially formalized system to a social system that integrates new cognitive approaches.

To summarize, there is a growing craze among researchers, especially in strategic management who recognize the cognition of managers as an emerging field of research and integrate into their work. It is for this reason that Ben Hassine and Ghozzi-Nékhili, (2013) building on Simon's work, point out that the manager is now a person with an essentially limited rationality called to treat the flow of information that he receives. In this case, the leader is no longer perceived as Homo oeconomicus animated by a perfect rationality as the neo-classics claim. The recognition of perceptions of leaders or decision-makers that result in an abundance of literature on their strategic decision-making process is considered an asset. Thus, the abundant growing literature in the field of CSR in SME context, testifies very opportunely the role of the manager in the interpretation of a strategy-oriented CSR. It is in this line of thought that the research that attempts to study the perception of managers or SME managers about CSR in a contingent context is included.

\subsection{Exploratory Study of the Perception of CSR Leaders in Cameroon's Forest Industry Sector: Methodological Choice Retained: the Multiple Case Study}

To better understand the representations, to understand the motivations and the obstacles of the commitment of the managers of SME of the forest sector in Cameroon regarding the CSR, we have conducted both a abductive and exploratory study based essentially on a qualitative methodology which is supported on the findings of a multiple case study (Eisenhardt 1989, Yin 2003). Our sample is made up of four Cameroonian SMEs from the forest industry sector divided into two groups, two of which are Forest Stewardship Council (FSC) certified and two non-certified. The choice of our cases focused mainly on the representativeness of the object of the research and not on the statistical arguments that should lead to generalization. It is probably for this reason that Ayerbe and Missonier (2007) emphasize that the originality of the case study is fundamentally based on the internal validity of its results, which is not the case for external validity. For Evrard et al., (2003), the relevance of a case study is based as much on the explanation as on the follow-up of a strict methodological protocol.

According to Ben Hassine and Ghozzi-Nékhili (2013), this approach aims not only at identifying social phenomena, but also at representing them and, consequently, at understanding them. Following 
Ndoumbe Berock et al., (2016) and Ben Hassine and Ghozzi-Nékhili, (2013), we also admit that a triangulation of data production modes has proved necessary not only to better understand our problem statement and interpret contradictions from the data collected, but also to minimize the bias inherent in the selectivity of memory (Mamboundou, 2016) of interviewees in order to ensure internal validity.

The first source consisting mainly of observations that the author was able to carry out as part of his doctoral research between March and September 2015, made it possible to explore Cameroon's excitement framework in terms of CSR and even sustainable development, to identify the Forest sector SMEs certified in fact and in practice, and finally gave us the opportunity to validate our interview guide. As a result, we participated in forums, conferences and seminars on forest governance in the Congo Basin, undertaking company visits and interviews with experts and managers in charge of forestry issues. The second source is documentary. Indeed, a literature search including a set of reports of general meetings of shareholders and boards of directors, associated with procedures manuals, including collective agreements governing logging activity in Cameroon context proved indispensable.

These documents were provided to us by companies, their website and by the Cameroonian Forest Administration, NGOs (WWF, Greenpeace, GIZ) and regional (COMIFAC) and international (ITTO, CIFOR, CIRAD) specialized in the forestry sector. Finally, the main source, known as the primary source of data, comes from transcripts of semi-structured interviews with SME managers, administered in "face-to-face" mode over a period of 4 months. The total duration of the interviews is 15 hours and 30 minutes. The interviews were not recorded. In fact, for the sake of confidentiality, almost all the managers interviewed systematically refused to be tape-recorded. The notes were taken under their watchful eyes and everyone could even make some amendments. Given the often busy schedule of these managers, interviews were conducted in two or three times to address all topics. This research has essentially as unit of analysis the leader. The adoption of our sample size was done at the end of the survey process. We proceeded gradually and by successive iterations to form our sample. We opted for a selection mode by reasoned choice for all elements. We have very opportunely exploited interviews with experts in a responsible approach to forest management in Cameroon (certification firms, forestry administrations, NGOs, etc.) to build our sample. We mainly relied on the law N 2010/001 of April 13, 2010 and articles 4, 5 and 6 promoting SMEs / SMIs in Cameroon.

According to the criteria PE and ME, the SME category includes companies with a permanent workforce consisting of 21 to 100 individuals and whose annual turnover excluding tax is greater than 100 million and not exceeding three billion FCFA according to the following classification:

- TPE: This refers to any company which employs at most 5 employees and whose turnover excluding tax does not exceed 15 million CFA francs;

- PE 6-20 employees and whose turnover excluding tax is between 15 and 250 million F CFA against 100 million previously;

- ME 21-100 employees for a turnover between 250 million and 3 billion CFA francs instead of 1 million previously.

According to statistics provided by the National Institute of Statistics (INS), this category of companies today represents more than $95 \%$ of the national economic fabric for a participation in the gross domestic product evaluated at $36 \%$. Therefore, the SME constitutes the rise of the Cameroonian economy, the essential source of its development. The objective pursued by this research consists, through a comparative approach, of presenting the perceptions of managers of Cameroonian SMEs in the forestry sector, engaged in a CSR approach and those of SME managers in the same sector who show no commitment and who are even at the extreme hostile.

As part of this research, we postulate that almost all SMEs committed to CSR comply with international standards in this area. They implement management systems for the environment, quality, health and safety at work and their employees. There are a multitude of standards that allow forestry sector companies in particular to operationalize (Imbs and Ramboarison-Lalao, 2013) their commitment to a CSR approach. The FSC forest certification was chosen as part of this work as the 
major tool justifying not only the commitment, but also the implementation of CSR practices by companies. Indeed, it is a matter of comparing perceptions, particularly in terms of motivations or limits in relation to the commitment of the companies studied in a CSR-oriented approach. In this respect, during the analysis, the points of resemblance and dissonance between the perceptions of the main actors will be identified and the supporting elements will be highlighted. We have consciously chosen to conduct this study in the same sector of activity to justify the heterogeneous behaviors existing in the sector and which obviously justify the relevance of such work. Table 1 below shows the characteristics of the four SME managers from the Cameroonian forest industry sector interviewed. The data collected were coded using axial coding, taking great care to respect the themes recorded in the interview guide; This strongly favors the selection of words or groups of words or verbatim with the same meaning. Subsequently, we analyzed them by referring to both content analysis techniques and thematic concomitances of Miles and Huberman, (2003). Specifically, the content analysis consisted in identifying the words that recurred in the speech of the actors interviewed and which helped to inform each theme. On the other hand, the thematic concomitance analysis favored a comparison between the respondents' responses according to each theme. Finally we have found it useful following Miles and Huberman, (2003) to adopt the usual approaches for inductive qualifying analysis (Miles and Huberman, 2003) by combining horizontal analysis and vertical analysis to build a matrix that highlights the similarities and dissonances in the CSR leaders' perceptions in the Cameroonian SMEs of the forest sector studied.

Table1. Characteristics of SMEs studied in Cameroon's forestry sector

\begin{tabular}{|c|l|c|c|c|c|c|c|c|}
\hline $\begin{array}{c}\text { Ruler } \\
\text { and } \\
\text { gender }\end{array}$ & Activities & $\begin{array}{c}\text { Date of } \\
\text { creation }\end{array}$ & $\begin{array}{c}\mathbf{2 0 1 5} \\
\text { Turnover } \\
\text { (FCFA) }\end{array}$ & $\begin{array}{c}\text { Number of } \\
\text { Employees }\end{array}$ & $\begin{array}{c}\text { Family } \\
\text { Character }\end{array}$ & $\begin{array}{c}\text { Certifica } \\
\text { tion }\end{array}$ & $\begin{array}{c}\text { Number of } \\
\text { Meetings }\end{array}$ & $\begin{array}{c}\text { Length of } \\
\text { interview }\end{array}$ \\
\hline $\begin{array}{c}\text { Alpha } \\
\text { Man }\end{array}$ & $\begin{array}{l}\text { Exploitation } \\
\text { and trading }\end{array}$ & 1996 & $\begin{array}{c}\text { Not } \\
\text { specified }\end{array}$ & 18 & No & FSC & 3 & $3 \mathrm{~h} 30$ \\
\hline $\begin{array}{c}\text { Beta } \\
\text { Man }\end{array}$ & $\begin{array}{l}\text { Forest } \\
\text { inventory }\end{array}$ & 1985 & $\begin{array}{c}\text { Not } \\
\text { specified }\end{array}$ & 11 & Yes & $\begin{array}{c}\text { Not } \\
\text { certified }\end{array}$ & 1 & $2 \mathrm{~h} 30$ \\
\hline $\begin{array}{c}\text { Lambda } \\
\text { Man }\end{array}$ & $\begin{array}{l}\text { Transformatio } \\
\text { n and trading }\end{array}$ & 1972 & 3 Billions & 50 & No & FSC & 2 & $4 \mathrm{~h} 00$ \\
\hline $\begin{array}{c}\text { Oméga } \\
\text { Man }\end{array}$ & $\begin{array}{l}\text { Exploitation, } \\
\text { transformation } \\
\text { and trading }\end{array}$ & 1994 & 2 Billions & 46 & Yes & $\begin{array}{c}\text { Not } \\
\text { certified }\end{array}$ & 3 & $5 \mathrm{~h} 30$ \\
\hline
\end{tabular}

Source: The author on the basis of the information collected

\section{FINDINGS}

Based on the dominant literature on CSR in SME context, like those ofSanguéFotso (2018),Ngaha Bah et al. (2016), Hassine and Ghozzi-Nekhili (2013), Simen and Ndao (2013), Ben Boubaker Gherib (2009) and Paradas (2006), we were able to identify the themes and establish our analysis grid regarding the perception of the leaders of these small and medium structures concerning CSR. The perception of Cameroonian forestry sector SME managers has been analyzed with reference to four central themes. First, we first tried to measure the level of familiarity or even familiarity of managers in this sector with the CSR concepts before looking at their priorities or concerns in this area. Then, we dwelt on the incentives and the obstacles to the engagement in a CSR-oriented approach to the companies of the sector under study.

\subsection{Knowledge or Familiarity of SME sector Leaders in Cameroon with the Concept of CSR}

While it is true that the leaders of companies in the forest industry sector in Cameroon are aware of the challenges of sustainable management of forest resources in the Congo Basin in general and in Cameroon in particular, it is clear that very few leaders in this sector are immersed in or better appropriate the concept of CSR and even less that of sustainable development. The analysis of the knowledge of the concept of CSR revealed that the managers of SMEs in this sector who are engaged in the CSR process have a partial knowledge of the concept of CSR and therefore are unfamiliar with the said concept. The three-dimensional character (triple line button) of the concept escapes the knowledge of the leaders. Only the leader of the Lambda case has proposed a definition that integrates all dimensions of CSR. For this manager, CSR is "the fact of taking into account the social and 
environmental aspects in its economic activities and its relations with all components of the company" (Lambda leader). During the analysis phase of the content of the respondents' interviews, we noticed that the environmental or ecological dimension is very important, particularly for SME managers involved in CSR (Alpha and Lambda leaders). "We are committed to ensuring that our activities include the environmental component as a priority" (Alpha leader).

In the same vein, the manager of the company Lambda emphasizes that "the many evils that undermine society, such as climate change, loss of biodiversity, etc. are strong sources of concern for us in the exercise of our activities." For leaders of Beta and Omega companies not involved in the CSR process, they still recognize that a responsible approach to environmental management contributes to the sustainability of their activities. This predominance of the ecological concerns of the companies studied seems to be justified by all the actions and incentive measures implemented by public authorities in this area. Moreover, the Cameroonian government, mindful of environmental issues, has created a whole ministerial Department dedicated to environmental issues and sustainable development. For example, audits are conducted periodically in forest sector companies by officials of the said ministry to find out how these companies manage their waste, reforest the pockets of exploited forests and parks. These companies are encouraged to carry out low impact logging. The social dimension is also a priority in these companies, particularly in certified companies that implement actions both for employees and local and neighboring populations. These two entities are perceived as the primary stakeholders (Alpha and Omega). Actions to promote social dialogue and to help improve the standard of living of employees are very remarkable within these companies.

In particular, in the case of Cameroonian managers who are not committed to CSR, we noticed during the analyzes that they, like other committed managers, have an approximate knowledge of CSR. This did not totally surprise us considering the lack of familiarity and the lack of commitment to CSR values. The social aspects but much more economical proved to be recurrent in the speeches of the actors interviewed (Beta and Omega managers). The social dimension is more pronounced in SMEs not engaged in a certification process. It is sometimes comparable to paternalism.

"If an employee is sick, the company takes care of all the expenses of hospitalization. When a worker has a problem, he finds comfort with the CEO, he gives at times motivations to employees to spend the weekend. He contributes every school year to the schooling of the employees' children, including even those employees who do not have children "(Comment from an Omega employee). It also concerns the relationship between managers and their employees and includes donations of all kinds granted to employees and multiform assistance to employees as well as local and neighbouring populations.

The environmental concerns in these entities concern the setting up of a forest management plan and its respect as prescribed by the law governing logging activity in Cameroon. Although not certified, some companies practice humanistic management (Arnaud, 2008) or informal CSR. "As for the human side, nothing is to blame in this company, I have not yet found a DG like this, he is not a businessman"(An employee's comment).

\subsection{Stimulants and Obstacles to Engaging in a Certification Process}

We have noticed in terms of incentives to engage in a CSR-oriented approach that discourse analysis reveals the predominance of a strong belief of managers in the commitment to CSR, especially in certified companies (Alpha and Lambda). "I strongly believe in the values of CSR" (Manager of an SME). This is what seems to justify the fact that the managers of these certified companies adopt proactive measures such as environmental policy to show their willingness to effectively engage in a CSR-oriented approach. The preservation of the company's image, its trust in its primary stakeholders and the credibility of its customers were mentioned in the speeches of managers, especially certified companies. The desire to respect forest regulations also seems to be a stimulus for some managers. The analysis has also shown that state incentives to SMEs influence the motivations or adherence of managers in a CSR-oriented approach. "We are committed to the responsible and sustainable management of the forests that have been granted to us as prescribed by the government in our specifications. This commitment guarantees not only the development of our company, but also the durability of our activities by strengthening our credibility with our partners "(A manager of a certified company). The pursuit of profit through commitment to CSR did not have a stimulating 
effect on some leaders. This is the case, for example, of Omega's eating which reveals to us that "the Smic [minimum wage] in Cameroon is 72 dollars USA in this company, the minimum basic salary is 156 dollars USA."

The data analysis also revealed that the corporate culture seemed to be a catalyst for managers, especially for the Alpha and Lambda cases. "We favor good relations with all our stakeholders" (about a manager). The values conveyed by CSR are likely to create an environment favorable to the adhesion of the employees. Strategic direction as a competitive advantage, was also mentioned by managers as a stimulator. CSR is perceived as a tool that does not only improves the image of companies, but it also ensures strong employee support.

Regarding the obstacles to commitment to a CSR-oriented approach, certified SME managers reveal the lack of material and financial resources. Indeed, as specified by a certified SME leader, "responsible logging requires advanced logistics, including low environmental impact gear."

The lack of communication and awareness of the state was revealed as an obstacle to the commitment of managers in a CSR-oriented approach. "This is the case, for example, of the Peasants Forests Committee (CPF), which is a structure created by the State to ensure that the concerns of local and neighbouring communities are taken into account in forest management. This structure has no means of operating. Some companies are forced to allocate an annual operating budget "(statement from a manager). The lack of state supervision and the setting up of real excitatory policies were mentioned as obstacles to the commitment of managers in a CSR-oriented approach. The corruption that plagues the sector does not favor this commitment at all. Another obstacle is impunity. For example, "companies pinned by the national flag of offenses in the sector, do not change behavior despite this denunciation. This is simply because the profits generated by the illegal activities are much higher than the almonds to pay "(statement from a manager). Some managers have cited the administrative burden and corruption as explanatory elements of the lack of commitment by some managers. The commitment to certification is considered by some managers to be irrelevant and perceived as unnecessary sources of expenditure for the company. This is probably the reason why the Omega SME manager had this to say:

"We are not a certified company and we do not intend to be one. We have found that it is a source of unnecessary expenses, there is no seriousness, it is a commercial activity for the certification bodies who do the masquerade and do not want to lose their clientele. All those who have embarked on this path are in trouble. However, we are in favor of the VPA / FLEG project because we believe that it is initiated by credible institutions (European Union and some countries), so it is serious. "

\subsection{A Comparative Analytical Approach to Different Perceptions of CSR}

During the interview analysis phase, we were able to observe SME managers interviewed, whether or not they were involved in a certification process, with similarities and dissonances. The conclusions that emerged regarding the knowledge and appropriation of the CSR concept reveal that "knowledge and approximate appropriation" represent a common point for both certified and non-certified SME managers. This is also the case for the strategic role played by employees in the process of integrating CSR, which was noted as a common point for these SME managers. This is what some authors describe as a social interpretation of CSR. We also noted that regulations represent for these entities an excitatory factor for the implementation of responsible practices, especially on the environmental side. These managers also denounce only the opportunistic behaviors of certain actors of the sector, in particular the corruption which represents a major obstacle to the societal engagement of these entities.

Notwithstanding these points of concordance, it is necessary to note the existence of certain points of dissonance. We have found that certified companies put more emphasis on the environmental dimension, which appears through the use of low-impact methods and harvesting equipment. Taking into account the interests of local and neighbouring communities through the preservation of sacred sites, the rights of use of forests, the use of local labor is also more important in the certified entities. Table 2 below presents a summary of the conclusions drawn from the comparative analysis relating to obstacles to the adoption of CSR-oriented practices. 
Perception of CSR by SME Managers: A Contextualist Analysis in the Forest Industry Sector in Cameroon

Table2. Synoptic presentation of resemblances and dissonances in managers' perceptions of CSR

\begin{tabular}{|l|l|l|}
\hline Similarities & \multicolumn{1}{|c|}{ Incentives } & \multicolumn{1}{|c|}{ Obstacles } \\
& $\begin{array}{l}\text { Promote the image of a responsible } \\
\text { company; } \\
\text { Guarantee credibility with partners and } \\
\text { customers; } \\
\text { Exercise of activities in compliance with } \\
\text { national and international regulations; } \\
\text { Display the culture of a socially } \\
\text { responsible company. }\end{array}$ & $\begin{array}{l}\text { State; } \\
\text { Absence of adequate logistics and financial } \\
\text { means; } \\
\text { Widespread corruption in the forestry sector; } \\
\text { Organizational hypocrite; } \\
\text { Nearly 8 ministerial Departments are involved } \\
\text { in logging activity (administrative burdens). }\end{array}$ \\
\hline Dissonances & $\begin{array}{l}\text { Paternalistic management for uncertified } \\
\text { SMEs; } \\
\text { The environmental dimension is very } \\
\text { important and put forward in certified } \\
\text { SMEs; } \\
\text { Preservation of achievements for } \\
\text { uncertified SMEs; } \\
\text { Opportunistic behavior for certified SMEs } \\
\text { of certification organizations by managers of } \\
\text { non-certified SMEs; } \\
\text { Perceived perception of the lack of objectivity } \\
\text { and the expected gains in the commitment to a } \\
\text { CSR-oriented approach (uncertified SMEs); } \\
\text { Well-known perception of state indifference to } \\
\text { encourage organizations committed to a CSR- } \\
\text { oriented approach (certified SMEs); }\end{array}$ \\
\hline
\end{tabular}

Source: The author under the actors' speeches

\section{DisCUSSION OF FINDINGS AND MANAGERIAL IMPLICATIONS}

\subsection{Knowledge and Appropriation of the Concept of CSR}

This research is in line with those of SangueFotso (2018), Agha R. T (2017), Ngaha Bah et al. (2016), Ben Hassine and Ghozzi-Nekhili (2013), Simen and Ndao (2013), Labaronne and Gana-Oueslati (2011) and Gherib and M'hissen (2010) in an African context, relating to the major role of SME managers in the African context in the engagement of a CSR-approach. The comparative analysis of the speeches of the interviewed actors shows points of concordance and points of disagreement between the perceptions of SME managers in the Cameroonian forest sector engaged in a CSRoriented approach and those of SMEs not involved in this process. This analysis reveals a knowledge and a rough appropriation of these leaders of the concept of CSR. However, there is a lack of similarities in our results concerning the well-known concerns of managers with regard to CSR and the results highlighted by Ben Hassine and Ghozzi-Nékhili (2013).

In this respect, our results revealed that Cameroonian forestry sector managers define CSR by focusing primarily on its environmental dimension. Indeed, these managers feel concerned and challenged about the many challenges (climate change, loss of biodiversity, etc.) that the whole of humanity is faced with, according to Commenne et al., (2006). Bon and Taccola-Lapierre (2015) and Hakim Akeb et al. (2015) have noted the pervasiveness of the environmental dimension, which may have accentuated the confusion between CSR and the concept of sustainable development, usually annexed to the environment. In addition, following Gherib and M'hissen (2010) and Ben Hassine and Ghozzi-Nékhili (2013), our results reveal the existence of informal CSR practices in Cameroon's forest sector SMEs.

\subsection{Incentives for Commitment to a CSR-Oriented Approach}

Following analysis of the interviews of the main actors of SMEs, we arrived at the results which corroborate those of Gherib and M'hissen (2010) and Ben Hassine and Ghozzi-Nékhili (2013) in the Tunisian context, and Bon and Taccola- Lapierre (2015) in the French context. Indeed, we have noted, like these authors, a meager illustrative power of the normative and mimetic isomorphisms of SME managers in a Cameroonian context. Certified organizations that are driven by the desire to satisfy and maintain the trust of their trading partners (patronage) are more inclined to subject themselves to compliance with national and international regulations, reinforcing de facto the merits of coercive isomorphism. Our results reinforce those of Gherib and M'hissen (2010), Ben Hassine and GhozziNékhili (2013) and Bon and Taccola-Lapierre (2015), presenting the national incentive framework as a factor likely to stimulate SMEs that are still skeptical to embrace resolutely CSR and indirectly, sustainable development. It is also necessary to stop the delay, to establish a frank communication and 
that the State implement appropriate policies to combat corruption and impunity that create a major obstacle to scrupulous compliance with regulations.

Our results also show that an SME's commitment to a CSR-oriented strategic approach is closely linked to the manager's own values and personal aspirations. Among other things, we observed during the data analysis that the leaders of SMEs embarked on the forest certification process and even sustainable development path, are endowed with a rather remarkable personal and entrepreneurial conviction, which is not the case for managers of non-certified entities. These conclusions are consistent with those of Ben Hassine and Ghozzi-Nékhili (2013) and Hakim Akeb (2015) in a Tunisian and French contexts which, based on a comparative analysis of theories, notably neoinstitutional and entrepreneurial, demonstrate the primacy or better the ease of the entrepreneurial theory to better explain the adherence of managers of SMEs on the path of CSR.

In the case of certified SMEs, managers are pursuing a strategic watch which consists in finding sources of motivation to remain in the CSR-oriented approach and admit them not "as a source of useless expenses" as some SME managers. who are not engaged in the forest certification process think, but rather as a source of competitive advantages to be preserved. Very clearly, the managers of SMEs lead their entity in a responsible way. This responsible approach is materialized by the implementation of innovative CSR practices (Berger-Douce, 2011). Our results reveal that SMEs that are not engaged in a CSR-oriented approach are run by managers who are only concerned with the short term, they are not engaged in a strategic and innovative vision that is in the long term. These leaders are not interested in strategic intelligence, especially in the search for information or knowledge likely to stimulate them to change their minds and move towards a responsible approach. This is the case, for example, of Omega whose leader is categorically hostile to forest certification and does not intend to follow this path. This leader finds CSR useless because as he perceives it as a source of expenses and consequently finds no interest to engage in it (case of Beta). For this purpose, managers of Cameroonian SMEs in the forest industry sector could develop more proactive CSR strategies and go beyond what is codified by law. This result reinforces those of Ndoumbe Berock (2017) who point out that companies in the forest industry sector in Cameroon have a strong ability to anticipate societal pressures and demands. In terms of corporate image, we found that only certified companies that have access to the global timber market are concerned about their image (Alpha and Omega). SMEs that are not engaged in a CSR-oriented approach do not worry about their image, they have no pressure or concern to preserve their image since they do not have access to the market, they sell their productions to trading partners that are the other competing companies (Omega case). These results are similar to those of Ndoumbe Berock (2017). The corporate culture stands out in our work as an incentive for commitment to a CSR-oriented approach. In such a logic, corporate culture will migrate the efforts of all actors in the organization towards a common destiny and thus encourage the leader to engage in a responsible approach.

\subsection{Obstacles to the Commitment of SMEs in the Cameroon's Forestry sector to a CSR Process}

Our results showed that the financial resources generally put forward by SME managers as an obstacle to a responsible approach was not mentioned by the SME managers interviewed. Indeed, these SMEs have an average annual turnover of more than 2 billion CFA Francs. They have indeed a financial ease that cannot be an obstacle to their commitment to CSR and sustainable development. Our results are to this effect, contrary to those of some authors, notably Bon and Taccola-Lapierre (2015), Hakim Akeb et al., (2015), Gherib and M'hissen (2010), which reveal that the managers of SMEs perceive the lack of financial resources or even the financial vulnerability of SMEs as a major obstacle to the societal commitment of these entities. On the other hand, the absence of communication, the administrative burden, the bad perception or the total lack of perception of the interest in the commitment to a CSR-oriented approach constitute major barriers for the adhesion of these SMEs . CSR-oriented. Our results corroborate those of Bon and Taccola-Lapierre (2015), Hakim Akeb et al., (2015), Labaronne and Gana-Oueslati, (2011) and Gherib and M'hissen, 2010). We also highlighted widespread corruption in the sector studied, impunity and the lack of state incentives as well as other obstacles to SME engagement in a CSR-oriented approach.

The absence of similar work in the Cameroon context, led us to compare our results with those of some authors, particularly in the French and Maghreb contexts, which reveals a particular interest in 
our problem statement. The empirical study conducted by M'Hamdi and Trid (2009) on a sample of some 40 companies, all based in Morocco, shows that 62.9\% of SME managers studied in the FèsBoulemane region assert that not only do they know about CSR, but also its stakes and benefits and the main obstacles to its implementation. These results are not surprising because Morocco is considered one of the few countries in Africa and particularly in the Maghreb whose employers have particularly invested in setting up a CSR label specific to organizations operating in the Moroccan territory. It emerges from this study that the assets to the commitment of the companies to a CSRoriented approach are essentially of an economic nature. Indeed, CSR is viewed by Moroccan-based business leaders as an essential tool not only to retain business partners (customers), but also to improve relationships with all stakeholders to ensure better economic performance. The obstacles to the adhesion to a CSR-oriented approach relate specifically to the lack of both financial and human resources associated with the lack of time dedicated to such a commitment.

It is clear that the managers of the Maghreb companies are more advanced in terms of knowledge and familiarity with the concept of CSR than the Cameroonian SME managers interviewed. Fortunately, with regard specifically to motivations and obstacles, there are some points of similarity with the Cameroonian SMEs studied (expected economic performance, customer loyalty tool, etc.).

\section{CONCLUSION}

The objective of this research was to analyze the perception of CSR by SME managers in Cameroon's forest industry sector. We opted for a qualitative research, including an exploratory survey based on a multiple case study of four Cameroonian SME managers, two of whom are formally involved in a CSR-approach via FSC forest certification, and two SMEs not involved in a forest certification process. The results of the comparative analysis of the managers' interviews, through the four SMEs studied, reveal that the managers of SMEs in the Cameroonian forest sector in both cases have a very approximate familiarity with the concept of CSR. This justifies the fact that only one SME executive gave a concise definition of CSR, taking great care to integrate the three dimensions (economic, social and environmental) of this concept. The environmental dimension, on the other hand, is very significant in the speeches of the leaders interviewed, thus making the ecological aspect the most important or even the most worrying for all the managers of the studied sector (certified and not certified). The preservation of the brand image associated with the desire to retain the primary stakeholders (employees, customers, etc.) in the sense of Clarckson (1995) and to comply with the regulations is a real catalyst for adhering to a CSR-oriented process for managers of certified SMEs. On the other hand, we have noted that these elements are not perceived by the managers of SMEs that are not certified like motivating factors.

The major obstacle to engaging in a CSR-oriented approach common to the two categories of SMEs studied concerns the lack of communication, coupled with a lack of knowledge on the issues and even the expected benefits relating to CSR. Moreover, the corruption associated with a notorious impunity of the corrupt actors who are constantly pinned by the base of the infractions observed in the sector is the privilege of the operation of many Cameroonian forest enterprises. Therefore, we suggest that Cameroonian SME managers in the forestry sector who are still skeptical about the stakes and benefits expected from the commitment to a responsible management of forest resources to go ahead with their commitment; which would be likely to constitute, in the sense of Porter and Kramer (2007), a durable competitive advantage. Any SME manager in the forest sector in Cameroon should be aware and convinced that CSR is a real opportunity to transform the running of their business and to position themselves as a responsible company. We also recommend that the Cameroonian Government support the managers of Cameroonian SMEs in the process to a voluntary CSR approach by developing incentives for this purpose.

The results obtained within the framework of this research are far from being generalizable, in particular because of the methodology adopted which has concentrated on a study of four cases. While we are aware of these methodological limitations, it worth recalling that the main purpose was to examine the perceptions of Cameroonian SMEs in the forest industry sector with regard to CSR and to callipso facto the attention of researchers to the prospects for research work on CSR issues in African companies, in line with the recommendations of Ndoumbe Berock (2017). Also, it would be 
interesting, in future research, to continue this reflection by integrating several sectors of activity and several cases of companies located in the Central Africa sub-region, which, in our opinion, seems to be a method consistent with a generalization (Mamboundou, 2016) and actionability (David, 2005) of CSR issues in Africa.

\section{REFERENCES}

[1] Abdirahman Z-Z. et Sauvée L. (2011), Un réseau pour l'adoption de la RSE dans les PME agroalimentaires : le cas Destination Développement Durable, dans les Actes du 6e Congrès du Réseau international de recherche sur les organisations et le développement durable, Luxembourg, 16 et 17 juin 2011.

[2] Agha R.T. (2017). Determinants of Sustainability: an objective indispensable for Micro Finance Institutions in Cameroon. International Journal of ManagerialStudies and Research (IJMSR), Volume 5, Issue 7, July, pp.42-69.

[3] Alemagi D and Kozak, R. A. (2010). Illegal logging in Cameroon: Causes and the path forward. Forest Policy and Economics, 12(8), 554-561.

[4] Alemagi, D. (2011). "Sustainable development in Cameroon's forestry sector: Progress, challenges, and strategies for improvement". African Journal of Environmental Science and Technology Vol. 5(2), pp. 6572.

[5] Arnaud S. (2008). Le management humaniste. Revue internationale de psychosociologie, 14(34), 207-224.

[6] Bayad M. et Garand D.J. (1998), Vision du propriétaire-dirigeant de PME et processus décisionnel : de l'image à l'action, dans la Communication au $4 \mathrm{e}$ Congrès international francophone de l'entrepreneuriat et de la PME, Metz, 22-23-24 octobre 1998.

[7] Beishem, M., Dingwerth, K. (2008), «Procedural Legitimacy and Private Transnational Governance. Are the Good doing Better? », SFB-GovernanceWorking Paper Series , 14.

[8] Ben Boubaker-Gherib J. (2009), De l'efficacité des systèmes incitatifs pour l'engagement des entreprises dans le DD : cas des entreprises tunisiennes, dans les Actes du Colloque : énergie, changement climatique et développement durable, Université de Tunis El-Manar, 15-17 juin 2009.

[9] Ben Boubaker-Gherib J., Spence M. et OndouaBiwolé V. (2009), Développement durable et PME dans les pays émergents: entre proactivité, opportunisme et compromis, Journal of Small Business and Entrepreneurship, 22, 3, 275-295.

[10] Ben Hassine L et Ghozzi-Nékhili C. (2013). «Perception de la responsabilité sociale des entreprises par leurs dirigeants : Une comparaison entre PME tunisiennes certifiées et non certifiées » Revue internationale P.M.E. 262 : 59-80. DOI: 10.7202/1024321ar.

[11] Berger-Douce S. (2007), Les stratégies d'engagement sociétal des entrepreneurs, Revue de l'Entrepreneuriat, 6, 1, 53-71.

[12] Berger-Douce S. (2009). Management de la diversité et performance en PME, dans les Actes du Colloque international : la diversité, questions pour les sciences sociales - égalité dans l'emploi, discrimination au travail et management de la diversité, École de management de Strasbourg, 2 et 3 décembre.

[13] Berger-Douce S. (2011). Le développement durable, un levier d'innovation pour les PME ? Revue française de gestion, (6), 147-166.

[14] Bon V et Taccola-Lapierre S. (2015). «La performance sociétale des PME engagées dans la RSE : des fondements aux enjeux de son explication ». Revue de l'Organisation Responsable, Vol.10, №2, 5-27.

[15] Boström, M. (2006), «Regulatory Credibility and Authority through Inclusiveness: Standardization Organizations in Cases of Eco-Labelling », Organization, 13 (3), p. 345-367.

[16] Capron M et Quairel, F. (2007). La responsabilité sociale d'entreprise, Coll. Repères, La Découverte.

[17] Carroll, A. B. (1979). «A Three-DimensionalConceptual Model of Corporate Performance », Academy of Management Review, 4, (4), pp 497-505.

[18] Carroll, A. B. (1991). «The Pyramid of Corporate Social Responsibility: Toward the Moral Management of OrganizationalStakeholders», Business Horizons, No 34, p.39-48.

[19] Cashore B et al., (2005). «Private or self-regulation? A comparative study of forest certification choises in Canada, the United States and Germany ». Forest policy and economics, 7, p.53-69.

[20] Cerutti P. O, Lescuyer, G, Tsanga R, Kassa S. N, Mapangou, P. R, Mendoula, E. E., ... et Yembe, R. Y. (2014). Impacts sociaux de la certification du Forest Stewardship Council : evaluation dans le bassin du Congo (Vol. 105). CIFOR.

[21] Christine Noël (2004). La notion de responsabilité sociale de l'entreprise : nouveau paradigme du management ou mirage conceptuel ? Gestion 2000, $\mathrm{n}^{\circ} 3$, Septembre Octobre pp15-33. 
[22] Clarkson M.B.E. (1995). A stakeholderframework for analyzing and evaluatingcorporate social performance. Academy of Management Review, 20(1), 92-117.

[23] Commenne V, Champion E., Gendron C, Ramaswany R, Munoz I et Atidegla, A. (2006). Responsabilité sociale et environnementale des acteurs économiques. Mode d'emploi pour plus d'éthique et de développement durable.

[24] Cossette P. (2003), Méthode systématique d'aide à la formulation de la vision stratégique : illustration auprès d'un propriétaire-dirigeant, Revue de l'Entrepreneuriat, 2, 1, 1-18.

[25] Dejean F. et Gond J.P. (2004). La responsabilité sociale des entreprises : enjeux stratégiques et méthodologies d recherche, Finance Contrôle Stratégie. Volume 7, No 1, mars, p. 5 - 31.

[26] DiMaggio P. I and Powell W. W. (1983). The iron cage revisited: Institutional isomorphism and collective rationality in organizational fields. American SociologicalReview, 48, 147-160.

[27] DiMaggio P. J. and Powell, W.W. (1991). The new institutionalism in Oraganizational Analysis, Chicago, The University of Chicago Press, 478p.

[28] Durif F. (2006). «Vers un modèle de responsabilité sociale intégrateur en stratégie : une source d'avantage concurrentiel et un impératif stratégique ». Cahier de recherche de l'école des sciences de la gestion de l'UQAM.

[29] Ehlinger S. (1997), L'approche sociocognitive de la formation de la stratégie : apports théoriques et méthodologiques, dans les Actes de la 6e Conférence internationale de l'Association internationale de management stratégique, Montréal, 24-27 juin 2008.

[30] Eisenhardt K. (1989), Building theoryfrom case studyresearch, Academy of Management Review, 15, 4, 532-550.

[31] Eisenhardt K. M. (1989). Agency theory: an assessment and review. Academy of Management Review, Vol 14, pp. P. 57-74.

[32] Evrard Y, Pras, B and Roux E. (2003). « Market, études et recherches en marketing fondements et méthodes ». Nathan, Paris.

[33] Fassin Y., Van Rossem A. et Buelens M. (2011), Small-business owner-managers' perceptions of business ethics and CSR-related concepts, Journal of Business Ethics, 98, 3, 425-453.

[34] FenjouNjoya M-L. (2011). "Exploitation minière et forêt : enjeux pour le développement durable au Cameroun". 16ème colloque international en évaluation environnementale organisée par le SIFFE, 12-15 septembre Yaoundé- Cameroun.

[35] Gendre-Aegerter D. (2008), La perception du dirigeant de PME de sa responsabilité sociale : une approche par la cartographie cognitive, Thèse de doctorat en sciences économiques et sociales, Université de Fribourg (Suisse), 584 p.

[36] Gherib J. et M'hissen I. (2010), Engagement environnemental et taille de l'entreprise : une lecture à travers la théorie néo-institutionnelle, dans les Actes de la 19e Conférence de l'Association internationale de management stratégique, Luxembourg, 2-4 juin 2010.

[37] Gherib J. et M'hissen I. (2010), Engagement environnemental et taille de l'entreprise : une lecture à travers la théorie néo-institutionnelle, dans les Actes de la 19e Conférence de l'Association internationale de management stratégique, Luxembourg, 2-4 juin 2010.

[38] Hakim et al., (2015). «Analyse exploratoire de la mise en œuvre des trois dimensions de la RSE dabs les PME françaises ». Revue de l'Organisation Responsable, Vol.10, N², 5-27.

[39] Imbs P etLovanirinaRamboarison-Lalao. (2013). «Opérationnaliser la RSE dans les PME : quelles pratiqu es de GRH socialement responsables ? », Management \& Avenir 1 ( $\mathrm{N}^{\circ}$ 59), p. 35-55. DOI 10.3917/ mav .059 .0035

[40] Jenkins H. (2009), A business opportunity model of corporate social responsibility for small-and mediumsizedenterprises, Business Ethics : A EuropeanReview, 18, 1, 21-36.

[41] Labaronne D. et Gana-Oueslati E. (2011), Analyse comparative Maroc-Tunisie du cadre institutionnel de la RSE dans les PME, Management et Avenir, 43, 103-121.

[42] Labelle F. et Aka K.G. (2010), Le business case pour la responsabilité sociale des entreprises adapté aux PME 5 cas québécois, Entrepreneurial Practice Review, 1, 3, 69-85.

[43] Lauriol J. (1998), La Stratégie comme principe d'action, dans les Actes de la 7e Conférence de l'Association internationale en management stratégique, Louvain, mai.

[44] M'Hamdi M. et Trid S. (2009), La responsabilité sociale de l'entreprise au Maroc : une étude empirique auprès des petites et moyennes entreprises de la région de Fès Boulemane, Colloque La vulnérabilité des TPE et des PME dans un environnement mondialisé, Université du Québec à TroisRivières, 27- 29 mai 
[45] Mamboundou J. P. (2016). De la gestion de l'information RH à la gestion de la citoyenneté organisationnelle $(\mathrm{CO})$ : pratiques managériales et réactions des salariés dans les entreprises gabonaises. Question (s) de management, (1), 45-60.

[46] Matten D and Moon J. (2005). Corporate social responsibility. Journal of business Ethics, 54(4), 323-337.

[47] McGinley K et Cubbage F W. (2011). «Governmentalregulation and nongovernmental certification of forests in the tropics »: Policy, execusionuptake,andoverlap in Costa Rica, Guatemala, and Nicaragua. Forest policy and economics, 13, p.206-220.

[48] Meehan, S. M., Kraus, M. D., Kadambi, P. V and Chang A. (2006). Nephron segment localization of polyoma virus large T antigen in renalallografts. Humanpathology, 37(11), 1400-1406.

[49] Meindl J.R., Stubbart C. et Porac J.F. (1994), Cognition within and betweenorganizations : five key questions, Organization Science, 5, 3, 289-293.

[50] Miles B.M. et Huberman A.M. (2005), Analyse des données qualitatives : recueil de nouvelles méthodes, Bruxelles, De Boeck-Wesmael, 480 p.

[51] Mintzberg H. (1973), Strategy-making in three modes, California Management Review, 16, 2, 44-53.

[52] Ndoumbe Berock. I.B, et al.,.(2016). « Les pratiques de la RSE par les entreprises d'exploitations forestières dans le Bassin du Congo : conformisme ou volontarisme?», Revue de l'organisation responsable, vol. 11, no.2, p. 55-63. DOI 10.3917/ror.112.0055.

[53] Ndoumbe Berock. I.B. (2017). Construction de la responsabilité sociétale des entreprises (RSE) dans les pays en développement: une application dans les entreprises d'exploitations forestières au Cameroun. Thèse de doctorat soutenue publiquement à l'Université de Strasbourg.

[54] Ngaha Bah A, AssaneNdao, FatouSall et Bassirou Tidjani. (2016). La responsabilité sociétale des toutes petites, petites et moyennes entreprises en Afrique: un mythe en marche au Sénégal? . 27ième congrès de l'AGRH, Strasbourg, France. <hal-01688341>.

[55] Nielsen A.E. et Thomson C. (2009), CSR communication in small and medium-sizedenterprises : astudy of the attitudes and beliefs of middle managers, Corporate Communications : An International Journal, 14, 2, 176-189.

[56] Nkakleu R. (2016). «Les pratiques de GRH des PME africaines sont-elles toujours informelles ? Une analyse contextualiste », Question(s) de management, 1( $\left.\mathrm{n}^{\circ} 12\right), \mathrm{p} .83-104$.

[57] OndouaBiwolé V., Spence M. et Ben Boubaker-Gherib J. (2008), Stratégies de développement durable dans les PME: une étude exploratoire auprès des PME camerounaises, dans les Actes du 9e Congrès international francophone en entrepreneuriat et PME, Louvain-La-Neuve, Belgique, 29-31 mai 2008.

[58] Paradas A. (2006). Perception du développement durable par des dirigeants de petites entreprises: résultats d'enquêtes, dans les Actes du 8e Congrès international francophone en entrepreneuriat et PME, Suisse, 25-27 octobre.

[59] Paradas A. (2011), Développement durable en petites entreprises : de la sensibilisation à l'engagement, La Revue des Sciences de Gestion, 1, 247-248, 129-137.

[60] Pippla M. (2013). «Forest certication and trust : Differentroles in differentenvironments ». Forest policy and economics, 31, p.37-43.

[61] Quairel L. F. et Auberger M.N. (2005), Management responsable et PME : une relecture du concept de responsabilité sociétale de l'entreprise, Revue des Sciences de Gestion : Direction et Gestion, 40, 211212, 111-126.

[62] Quazi A. M and O'brien D. (2000). An empirical test of a cross-national model of corporate social responsibility. Journal of business ethics, 25(1), 33-51.

[63] Sangué-Fotso R. (2018). «Perception de la RSE par les dirigeants de PME camerounaises » RIPME, volume 31-numéro 1.

[64] Schneider S.C. et Angelmar R. (1993), Cognition in organizationalanalysis : who'sminding the store ?, OrganizationsStudies, 14, 3, 347-374.

[65] Simen S.F etNdao A. (2013). «L'effet de la mise en place d'une stratégie de Responsabilité Sociale de l'entreprise sur la culture organisationnelle : Analyse, implications et enjeux pour le Sénégal », Revue Congolaise de Gestion 1 (Numéro 17), p. 131-170. DOI 10.3917/rcg.017.0131

[66] Spence M., OndouaBiwolé V. et Ben Boubaker-Gherib J. (2007). Une étude exploratoire des fondements du degré d'engagement des PME dans le développement durable, dans les Actes des 10e Journées Scientifiques du réseau entrepreneuriat de l'Agence universitaire de la francophonie, Antananarivo, 23-26 mai 2007.

[67] Walsh J.P. (1995), Managerial and organizational cognition : notes from a trip down Memory Lane, Organization Science, 6, 3, 280-321. 
[68] Wood D. J. (1991). Corporate social performance revisited. Academy of management review, 16(4), 691718.

[69] Yin, R.K. (1984). Case studyresearch: Design and methods (1st Ed.). Thousand Oaks, CA: SAGE.

\section{AUTHORS' BIOGRAPHY}

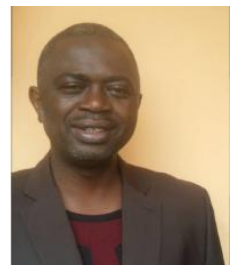

Isaac Bernard NDOUMBE BEROCK holds a Ph.D. in Management Sciences, supported on May 19, 2017 in Strasbourg, France, which is part of a framework agreement for international cooperation between the Faculty of Economics and Management Sciences ( FSEG) of the University of Strasbourg option Management and Strategy and the School of Economics and Commerce (ESSEC) of the University of Douala in Cameroon, option Management of Human Resources. The subject of his thesis is entitled: "Construction of Corporate Social Responsibility (CSR) in developing countries: an application in logging companies in Cameroon".

Dr. Isaac Bernard NDOUMBE BEROCK is an organizational strategist in the fields of Organizational Development, Business Management, Human Resources Management, Formulation of Strategies for Change Management and Innovation, Human Resources Marketing. This research focuses on CSR, sustainable development and Innovation in organizations, particularly in the forestry sector in the Congo Basin. He is also consultant for many companies in the forest industry sector in the Central Africa subregion. Dr. Isaac Bernard NDOUMBE BEROCK is a visiting lecturer in several public and private Higher Institutes in Africa. He is assistant professor of permanent conferences at the ESSEC Human Resources Management Department in Cameroon.

Citation: Dr Isaac Bernard NDOUMBE BEROCK. " Perception of CSR by SME Managers: A Contextualist Analysis in the Forest Industry Sector in Cameroon" International Journal of Managerial Studies and Research (IJMSR), vol 6, no. 8, 2018, pp. 9-25. doi:http://dx.doi.org/10.20431/2349-0349.0608002.

Copyright: () 2018 Authors. This is an open-access article distributed under the terms of the Creative Commons Attribution License, which permits unrestricted use, distribution, and reproduction in any medium, provided the original author and source are credited. 